\title{
NEM TUDO É VALENTIA OU VADIAGEM: práticas culturais e usos de símbolos de civilidade por escravos, forros e mestiços na Província do Maranhão oitocentista
}

Mariléia dos Santos Cruz

Professora do Departamento de Educação I/ Pedagogia da UFMA. Doutoranda em Educação Escolar pela FFCL-UNESP/Araraquara-SP.

Resumo: O presente estudo visa caracterizar práticas e usos de símbolos de civilidade por escravos, forros e mestiços na Província do Maranhão, destacando-se o uso da leitura e a escrita no contexto das irmandades de pretos durante o século XIX. Utiliza anúncios da imprensa maranhense e documentos de arquivo.

Palavras-chave: século XIX; escrita; escravos; forros.

Abstract: This work describes the practice and use of characteristic civilized symbol by slave, free, and half-caste in Province of Maranhão. In these work we give emphases to use of learning and writing. It uses as source the press of Maranhão in century XIX and paper from public file.

Key-words: century XIX; learning; slave; free.

\section{Introdução}

O estudo sobre as relações sócio-raciais durante os séculos de escravidão no Brasil tem sido objeto de uma vasta bibliografia que, em detalhes, discorre sobre os rigores dos castigos físicos aplicados aos escravos, mecanismos legais usados para regulamentar a escravidão desde sua ascensão até a sua processual extinção, e também sobre as várias formas de resistência negra à condição imposta.

Contudo, infelizmente esta vasta bibliografia ainda corresponde a uma realidade "à parte" no contexto do que se considera oficialmente como a História do Brasil. Há a História do Brasil, com seus ciclos econômicos, com suas políticas modernizadoras, com suas revoltas, com referências a seus líderes administrativos (governadores gerais, 
presidentes de províncias, imperadores e presidentes); e há, como complemento, a História da Escravidão no Brasil. Oficialmente este é um tópico nos livros didáticos destinados à educação das novas gerações. Quem não saberia descrevê-lo? Encontram-se nas limitadas páginas destinadas a esse assunto textos que falam da procedência dos negros, das atividades desenvolvidas durante o sistema, das leis que instituíram a liberdade gradual Proibição do Tráfico Negreiro (1831) e seu efetivo fim (1850), Lei do Ventre Livre (1871), Lei do Sexagenário (1885) e Lei Áurea (1888). De forma complementar às informações escritas, aparece uma vasta coleção de obras de arte que retratam esse período. São quadros de Debret e Rugendas que descrevem cada momento da vida escrava: nos navios, nos mercados, como vendedores urbanos, no pelourinho, na casa grande, na senzala e assim por diante... Esta é a História do Brasil: uma história que no decorrer dos seus 507 anos, demarcados a partir da colonização européia, pelo menos mais de 300 anos se desenvolveram sobre a agonia da exploração negra. Fato que, não só destaca um dos países que mais explorou o trabalho escravo africano no mundo ${ }^{1}$, mas que marcou, indubitavelmente, a vida passada e presente de um continente inteiro de onde foram retirados tantos seres humanos.

Não seria viável que a exceção virasse regra? Como falar da História do Brasil sem dar os tons da cor negra a todos os tópicos da História, em todas as fases e detalhes sobre o desenvolvimento desse país? Como não citar quilombos que se instituíram na escravidão contra o que os líderes políticos lutaram tanto, mas que permanecem, em muitos casos até hoje? Como falar dos cidadãos brasileiros ignorando os tantos tons de peles negras e tantos outros caracteres fenotípicos imprimidos na população atual? Como falar de cultura brasileira ignorando os tantos interesses musicais, culinários, medicinais, religiosos, plásticos e gingas corporais que apontam ao Brasil uma matriz africana? Com a mesma pergunta poderíamos lembrar outros aspectos da economia, da literatura, da educação, da vida cotidiana...

Embora sendo explorada como história à parte, parecem-nos indiscutíveis as contribuições dadas pelos trabalhos que retratam a vida escrava no Brasil sob o âmbito legal, econômico, da resistência ou dos castigos para compreensão da realidade brasileira.

\footnotetext{
${ }^{1}$ Segundo Mattoso (2003, p. 53) até 1850, o Brasil teria importado 38\% de escravos trazidos da África para o Novo Mundo.
} 
Contudo, devemos ressaltar que a representação que se construiu em grande parte dos estudos tem se restringido à participação histórica dos negros em aspectos excludentes: ora são situados como submissos, dóceis e de alma naturalmente servil; ora são personificados como subversivos, rebeldes e revoltados.

Chama-nos atenção que ambas as abordagens incorrem no perigo da generalização que mistifica e estereotipa, fazendo-nos crer que os negros ou estiveram muito aquém do seu tempo ou muito além dele.

O presente texto visa refletir sobre as práticas sociais e usos de símbolos ligados à idéia de civilidade por escravos, forros e mestiços na Província do Maranhão durante o século XIX, e busca contribuir com os trabalhos que demonstram a limitação de abordagens sobre a escravidão, cuja representação das populações negras se restringem a dois pólos antagônicos. Sendo assim, orienta-se pela hipótese de que os negros do passado, do mesmo modo que os atuais, estiveram impregnados no seu tempo, no seu contexto, participando dele, influenciando-o, quer seja intencionalmente ou não, e sendo influenciados de diversificadas formas.

\section{Práticas de apropriação cultural de símbolos de civilidade por escravos, forros e mestiços}

A expressão civilização foi uma das mais utilizadas pelas elites durante a fase imperial do Brasil. A incorporação de boas maneiras, hábitos de higiene, assimilação no vestuário, conduta moral e religiosa foram práticas vivenciadas no contexto imperial visando aproximar a cultura brasileira o máximo possível dos modelos europeus (VAINFAS, 2002, p. 141). Os códigos de postura publicados constantemente nas províncias de todo o Brasil regulamentavam os "bons costumes" e visavam coibir todas as práticas que desvirtuassem o modelo estabelecido.

As práticas culturais de origem africana foram o principal foco dos grupos comprometidos com a civilização brasileira. Aos poucos as festas, os batuques, as danças, os ajuntamentos de pretos, a capoeira, os rituais religiosos foram se tornando caso de polícia. Ao mesmo tempo, estar associado a estas práticas culturais passou a soar negativamente produzindo o distanciamento dos sujeitos que almejavam gozar de boa aceitação social. 
Almejar o modo de vida e as vantagens sociais concedidas aos de origem européia não deixou de fazer parte da realidade dos povos que viviam no universo social dos extratos mais baixos, onde estavam incluídos os escravos e os libertos num contexto em que o destino das pessoas parecia determinado pelas marcas da sua origem.

Sendo assim, parece-nos compreensível que fosse comum, por parte de negros, forros ou escravos, vislumbrar a inserção na sociedade estabelecida, buscando aproximar-se o mais possível do padrão humano que desfrutava mais plenamente das benesses.

Estar vinculado a uma confraria religiosa, pentear cabelos, usar sapatos, roupas de seda, roupas bem engomadas, usar chapéus, tocar instrumentos musicais de origem européia, fazer uso da escrita e leitura, são exemplos de práticas culturais cotidianas que vivenciadas por negros permitiam uma aproximação com a imagem de civilizados.

Tal questão pode ser compreendida se consideramos que alguns subalternizados visavam conquistar status semelhante aos que detinham o poder, quando se apropriavam de práticas culturais legitimadas como melhores e superiores. Os escravos que fugiam durante a primeira metade do século XIX, na Capital do Império, "procuravam ansiosamente adquirir os símbolos da liberdade, como sapatos, para esconder sua condição real" (SOARES, 2002, p. 83). Na imprensa maranhense do século XIX há evidências de que estas práticas não estiveram restritas ao contexto do Rio de Janeiro:

Nesta cidade desappareceu a escrava de nome Anna, mulata, cabello corrido, baixa, gorda, nariz um pouco chato, pertencente ao senhor José Demetrio Ferreira de Gusmão, do Mearim, a qual estava alugada ao Senhor Joaquim Antonio Ramos, estabelecido com padaria na Rua da Palma. Esta escrava costuma andar bem trajada, pelo que enculca-se livre. (O Paíz, 31 de agosto de 1878 , p. 3).

O escravo de nome Arcínio, de idade de 22 annos, pertencente aos herdeiros do casal do Barão de Bagé, acha-se fugido desde o dia 19 do corrente. E elle uma bonita figura, de boa estatura, magro, pouca barba, retinto, muito fallador. Official de carpina, pés grandes, nos quais tem calor de fígado, gosta muito de andar calçado e de roupa bem engomada, e quando anda é vergado para diante. Quem pois, o capturar, o entregar ao abaixo assignado, será bem gratificado. (Diário do Maranhão, $1^{\circ}$ de agosto de 1873, p. 4).

Fugio hontem da casa do abaixo assignado o seu escravo de nome Theodoro, preto crioulo de 22 anos de idade, pouco mais ou menos, bastante retinto, bons dentes, cabelos sempre penteados e apartados no meio, alegre e a amigo (...) e bem fallante-toca violão e pandeiro. Quem o capturar e entregar a seus senhores será bem gratificado [...] (Diário do Maranhão, 16 de junho de 1883 , p. 3).

Ao contrário dos discursos oficiais que quase sempre apresentava teor negativo sobre os negros, os anúncios por si demonstram um cotidiano que apesar da perceptível 
separação deflagrada pela cor da pele e características coadjuvantes, indicam que os negros se apropriavam de símbolos culturais desfrutados pelas classes privilegiadas, a exemplo do uso de vestuário com as qualidades instituídas pelas classes abastadas, muitas vezes como forma de passarem por livres. Embora nem sempre essa tenha sido a realidade de todos os escravos, conforme pode ser identificado na descrição feita por Emília Viotti da Costa quando se refere à forma com que muitos escravos se trajavam: "a maioria andava descalça e miseravelmente vestida; as mulheres mal cobriam o corpo com uma camisa e uma saia de tecido grosseiro, a cabeça envolta num pano, em forma de turbante. Os homens traziam o dorso nu, e uma calça de riscado" (COSTA, 1998, p. 276).

Sendo assim, enquanto havia negros que se encontravam em cativeiro e andavam com as vestes em farrapos (em conseqüência do limitado investimento dos senhores com o fornecimento de roupas para a escravatura) havia também outros negros que detinham maiores possibilidades de primar pela qualidade no vestir, como por exemplo os escravos domésticos, como mucamas ou negros e negras livres. Entre os negros que viviam mais próximos aos brancos, o vestir-se bem funcionava como um elemento de distinção que os levava a serem caracterizados como superiores aos demais. Segundo Costa (1998, p. 297) "o pouco dinheiro que o escravo conseguia acumular em horas de trabalho domingueiro [...] gastava com fumo, bebida, bugigangas e roupas".

Como se vê, a roupa está entre os símbolos de distinção utilizados por negros durante o século XIX. Estando bem vestido, tanto o escravo quanto o liberto, poderia se sentir mais semelhante ao senhor e assim, dispor de alguma visibilidade e aceitação. Contudo, essa aproximação não parece ter sido tão bem aceita pelos brancos. Tal fato se revela quando se lê no Publicador Maranhense, de 30 de novembro de 1861, um anúncio de venda de chapéus de sol importados de França, onde se destacam características específicas da mercadoria para homens, senhoras e mulatas. O que nos leva a inferir que mulheres brancas e mulheres de cor deveriam se diferenciar na qualidade do produto que utilizavam. O chapéu de sol para mulata era descrito como sendo de uma qualidade de tecido "superior aos que costumam vir a este mercado" (p. 2). O que demonstra que apesar de inferior aos do destinado às senhoras brancas, esse artigo poderia atingir um nível ainda mais inferior. Segundo Mattoso (2003, p. 221): 
Desde 1708 negros cativos ou libertos perdem direito de vestir tecidos de seda. As mulatas forras podem chegar até a ornar de tafetás os seus vestidos ou embelezar com meias de seda o garbo de suas pernas...; mas os passamanes, os botões de ouro ou de prata são proibidos aos mulatos, homens e mulheres, mesmo livres.

Nesta perspectiva, parece evidente que se as elites procuravam regular o modo de vestir dos homens e mulheres negros visando se distinguir destes, até porque, de alguma forma, em um contexto de questionável pureza de sangue ${ }^{2}$, poderia se tornar arriscado uma liberdade ampla na vivência comum de práticas culturais.

Contudo, as práticas sociais nem sempre estiveram restritas ao âmbito do uso de vestuário ou outros comportamentos culturais ligados à aparência. Outras práticas caracterizam a intenção dos negros em seu cotidiano de se apropriar de qualidades valorizadas pelos brancos, como detentores de boa oratória e bem articulados quanto ao uso de signos associados à vida livre, conforme pode ser observado nos anúncios seguintes:

Inculca-se forro, apresentando um título que requereu à coletoria, no qual se declara não achar-se elle matriculado, devendo assim ser, por ter apresentado por senha um terceiro. (O Paiz, 31 de março de 1878, p. 3)

Garante-se a gratificação de 200 mil reis a pessoa que capturar e entregar aos abaixoassignados o escravo de nome Augusto (...) de 20 a 22 annos de idade, bonita figura, bons dentes, corpulento, olhos grandes e vivos, estatura baixa, bem fallante e semblante alegre: intitula-se forro quando é escravo do Tenente Coronel José Coelho de Souza Junior, morador da Fazenda de Frechal, em Guimarães... (O Paiz, 07 de março de 1878, p. 4).

Os anúncios destacados, além de tantos outros que ocupam boa parte de páginas da imprensa do século XIX, não só no Maranhão, como também em outras Províncias, consistem em material riquíssimo para compreensão da vida dos escravos. Os anúncios de procura de pretos fugitivos podem ser importantes na desmistificação da idéia de que as práticas culturais dos afrodescendentes e dos descendentes de europeus estiveram bem separadas nos tempos da escravidão, uma vez que essa crença tem contribuído para justificar a consagração de diferenças sociais entre membros desses grupos. Essa questão é explicada pela pretensa incapacidade do negro de se assimilar ao modo de vida oficial do país e conseqüente impossibilidade de ascendência econômica, de inclusão no mundo escolar e do trabalho.

\footnotetext{
${ }^{2}$ Segundo Schwartz (2005, p. 211), o conceito de pureza de sangue foi utilizado desde o século XVI visando distinguir os que racial e politicamente se enquadravam no ideal do português branco e cristão-velho, não contaminados pela miscigenação com mouros, negros ou judeus.
} 
Dados enfocados por Mattoso aos analisar 471 testamentos de escravos libertos demonstram que os costumes dos negros detentores de propriedades não se diferenciavam das práticas correntes entre os brancos, embora estivessem ao mesmo tempo ligados aos valores culturais africanos adaptados à vida baiana. Para a autora, a reprodução de comportamentos ligados ao mundo europeu servia como forma de atingir conquistas sociais e econômicas (MATTOSO, 2003, p. 217).

Nesta mesma linha de análise, Mota (2005, p. 204-206) identifica que dentre um acervo de mais de 50 inventários pertencentes a moradores da Capitania do Maranhão localizados no Arquivo Histórico do Tribunal de Justiça, há cinco, cujos titulares são alforriados. Nestes inventários fica patente a vivência de relações familiares estáveis, a posse de escravos, de propriedades imobiliárias, e a adesão às irmandades, onde se reflete a preocupação cristã com a salvação da alma após a morte.

O testamento do africano Francisco José de Sousa, o qual identificamos no Jornal Diário do Maranhão, de 24 de fevereiro de 1882, exprime um pouco essa realidade. Vejamos melhor a questão suscitada na citação do testamento:

\footnotetext{
Testamento

E este o com que faleceu no dia 23 do corrente Francisco José de Souza, carpina:

Declarou ser christão natural da Costa d' áfrica, de nação Mina Nagô. Que foi casado com a Preta Liberta Romana Maria da Conceição, já falecida, de cujo matrimônio existem actualmente os seguintes filhos todos de maior idade: Isabel, casada, mas divorciada de seu marido Elias Francisco da Costa Belfort. Ezequiel, casado: Filomeno, casado; Francisco, casado: Elterio, solteiro e Libania, casada com Venâncio João da Cruz. Que deste matrimônio houve mais uma filha de nome Esperança, já falecida, mas presentemente representada por seu filho de Nome Bonifácio: Que ficam livres do cativeiro gratuitamente e sem condição alguma, suas escravas Luiza e Maria Raimunda, servindo-lhes esta verba de títulos. Que por falecimento de sua mulher deu partilha a seus filhos e neto: Quer que seu enterro seja simples, o corpo envolto em um lençol e acompanhado pelo respectivo vigário e cruz somente, que se digam missas por si e sua mulher e se distribua a quantia de 1.005 .000 pelos pobres que comparecerem a aquele acto, em esmolas de 500 reis. Nomeou seus testamenteiros, na ordem que vão inscriptos: Moises Joaquim Pinto, seu filho Ezequiel Francisco de Sousa, Francisco D` Assis Ribeiro do Amaral e Avelino José de Souza. (Diário do Maranhão, de 24 de fevereiro de 1882, p. 2).
}

$\mathrm{O}$ ato de deixar seu legado em testamento, bastante utilizado, entre os homens detentores de propriedade daquela época, aqui é realizado por um africano liberto. Como outros cidadãos, possuía escravos e repetiu o ato de dar esmolas aos pobres que comparecerem ao seu cortejo. Embora as fontes de que dispomos não evidenciem a forma como Francisco adquiriu sua liberdade e seus bens, o fato é que Francisco parece integrado na sociedade maranhense, o que também consta ter sido desfrutado pelos seus herdeiros. 
Ezequiel Francisco de Souza, herdeiro de Francisco que aparece no jornal do mesmo ano, em anúncio abaixo assinado, declara-se que "não é devedor a pessoa alguma"; mas se alguém se julgar seu credor deve apresenta-se ao prazo de 30 dias do aviso. No anúncio Ezequiel, filho do africano Francisco com a negra liberta Romana, indica dois endereços onde pode ser procurado, um que é residencial e o outro que é comercial: "estabelecimento Comercial do Senhor Souza Rosa e Correia", o que indica que Ezequiel trabalha no comércio, e como seu pai desfrutava de integração na sociedade maranhense. (Diário do Maranhão, 2 de março de 1882, p. 3).

O caso do testamento do africano por certo não representa algo comum no contexto social do Maranhão do século dezenove, mas mesmo assim torna-se um testemunho ilustrativo de que no quadro do Brasil escravista não havia apenas negros escravizados, ou libertos completamente aquém das práticas culturais ditas "civilizadas". Nem tão somente os negros envolvidos no mundo do crime, rebelados e culturalmente inalterados como forma de resistência ao sistema servil, ou vadios, ociosos como protesto a um sistema dependente do trabalho negro. Embora sejam estes alguns personagens da história do Brasil, por certo não são os únicos.

Há que se considerar outros personagens que se situam fora do que se convencionou como normal no contexto escravista, pois se é real que o Brasil se sustentou por mais de três séculos pela exploração escrava, também não deixa de ser real que além de negros na condição de escravo, por diversos mecanismos muitos negros também estiveram neste mesmo contexto na condição de livre, e como tal, por certo estiveram mobilizando esforços para se diferenciar dos que estavam como cativos. Mesmo os que estiveram na condição de escravo não podem ser tomados como um grupo homogêneo. Schwartz (2005, p.213), ao se reportar para as hierarquias sociais do Brasil escravista, afirma que:

As pessoas de cor livres formavam, na verdade, um grupo heterogêneo, com elementos de várias origens, locais de nascimento, habilidades, graus de aculturação e cores. Pouco havia de comum que os unisse, exceto a cor. A raça criara um sistema alternativo de estados_branco, pardo, negro, índio_que se fundiu com a sociedade européia e transcendeu. Se todos os negros tivessem sido escravos e todos os cativos, permanecidos cativos, a situação brasileira poderia ter se ajustado com pouquíssimas alterações aos princípios tradicionais de organização social. A complexidade originou-se da alforria de escravos e do nascimento de indivíduos mestiços, alguns nascidos livres e outros escravos, estes últimos sendo favorecidos no processo de manumissão. 
Ainda enfocando indicadores que evidenciam que durante a escravidão havia negros que se encontravam inseridos na sociedade, ocupando melhores posições sócioeconômicas durante o período da escravidão, Mota revela que durante o processo de ocupação do espaço urbano da ilha de São Luís pode-se identificar uma diversificação étnica em relação à posse de terrenos. De um total de 40 doações, no período de 1753 a 1759, um lote foi destinado a um "homem forro" cuja profissão era ferreiro; no período entre 1770 a 1779 de um total de 73 doações foram destinados dois lotes, um para uma mulher forra e outro para um homem forro; no período de 1780 a 1789 , de um conjunto de 290 doações, foram quatro para negros forros (um para preto forro oficial de pedreiro, um para mestiço forro oficial de sapateiro, um para preto forro e outro para uma preta forra) (MOTA, 1998, p. 56-57).

Embora os dados revelados evidenciem profundas desigualdades no processo de concessão oficial de terras em São Luís, por outro lado, quando nos detemos aos critérios que permitiam o acesso aos terrenos, podemos perceber que há uma demonstração de como também, neste caso, os negros, de alguma forma, forçaram uma ascensão social através da utilização de aparatos do poder, o que indica sinais de que estavam inseridos na sociedade e articulados com as formas de lidar com mecanismos legais formalizados pelo Estado. Isto ocorre quando se verifica que a concessão de lotes é subordinada a pedido por escrito direcionado à Câmara do Senado.

\section{Escrita e leitura como símbolos de civilidade para os negros: o caso das irmandades de pretos}

O acesso à leitura e a escrita por negros durante os anos de escravidão pode ter acarretado, de alguma forma, a conquista de maiores benefícios sociais aos indivíduos que fizeram uso destas ferramentas. O uso da escrita, por exemplo, poderia significar a própria ampliação da mobilidade social, pois pela assinatura do nome qualquer cidadão poderia dispor de maior trânsito na sociedade imperial.

Outras práticas sociais se faziam possíveis pelo uso da escrita. Mendonça (2001, p. 56) comenta sobre o tratado redigido por escravos rebelados em uma fazenda da Bahia, em 1789, no qual proponham condições para a volta ao cativeiro. Soares (2002, p. 105) relata que em 1836, no Rio de Janeiro, foi descoberta uma lista elaborada por pardos e 
pretos para formar um batalhão de guardas nacionais, o que, segundo o autor, foi considerado pelo escrivão da polícia como tentativa de insurreição. Outro caso interessante é destacado por Soares quando se reporta a tradições rebeldes no Rio de Janeiro. Segundo o autor, uma demonstração de que o jogo de capoeira praticado no Rio de Janeiro do início do século XIX não era uma atividade de "boçais", como se queria fazer pensar, pode ser evidenciado na ação de Manoel Coelho, crioulo forro, que, preso pela prática de capoeira, enviou ao intendente, um requerimento, escrito pelo próprio punho, em que pedia sua soltura" (SOARES, 2002, p. 78).

No caso do Maranhão, também há indícios de que ao longo do Século XIX havia negros forros e escravos apresentando conhecimento da escrita. Exemplos que caracterizam a questão são evidenciados em documentação oficial. Em 13 de setembro de 1865, o Presidente da Província Lafaiete Rodrigues Pereira, em ofício reservado, comunica ao Conselheiro José Tomás Nabuco de Araújo que "na Capital existiam pretos livres que sabiam ler sofrivelmente, e a quem não eram estranhas as idéias que naqueles tempos se vinham manifestando em favor da emancipação dos escravos" (ARAUJO, .2006, p. 27). Outro exemplo ocorre em período anterior, durante a Balaiada, quando o Negro Cosme é considerado perigoso não só pelas suas atitudes no âmbito do combate armado, mas também por suas atividades estarem além das específicas de guerra, voltadas para a vulgarização, entre os rebelados, dos conhecimentos das primeiras letras, conforme é evidenciado em ofício ${ }^{3}$ dirigido ao Secretário de Estado dos Negócios de Guerra no dia $1^{\circ}$ de setembro do ano de 1840:

O criminoso fugitivo da capital, por antigos crimes não punidos, é hoje importante figura, que mais assusta os fasendeiros, por achar-se á frente de dous mil escravos por elle sublevados: intitulando-se Tutor, e Imperador das Liberdades, procura attrair a escravatura com promessa de alforria; estabelleceu entre elles uma escola de ler, e escrever, e aquilombado nas cabeceiras do Rio Preto, commarca de Brejo, 14 Legoas distante do Acampamento da Vargem Grande na Fazenda da Lagoa Amarella pertencente ao cidadão Ricardo Nava, que me consta ter sido ultimamente assassinado, e a quem obrigarão antes de dar Carta de Liberdade a duzentos escravos seus (APEM, 2001, p. 269).

Ao nos reportamos às práticas de escrita por negros no século XIX, torna-se inevitável o estudo dos usos que se fazia desta prática no cotidiano das confrarias

\footnotetext{
${ }^{3}$ Balaiada: insurreição popular que ocorreu na Província do Maranhão no período de 1839-1841. Foi liderada por Raimundo Gomes, conhecido como Balaio e o Negro Bento Cosme, líder quilombola.
} 
religiosas, nomeadas de irmandades. As Irmandades foram consideradas como espaços importantes da organização comunitária no contexto do Brasil colonial e imperial. Consistiram em entidades leigas de caráter religioso que se agregavam nas igrejas católicas congregando seus membros em torno de um santo de devoção comum, proteção mútua e realização de obras caritativas. Essas entidades eram mantidas por contribuição de seus membros e por doações de particulares, muitas vezes contempladas em testamentos.

Embora sendo a adesão a uma irmandade prática social corrente entre os homens "bem nascidos" da época, a visibilidade ou prestígio decorrentes dessa adesão despertava interesse também nos membros de classes sociais menos abastadas, ou até completamente excluídas como era o caso dos escravos. Sendo assim, enquanto algumas entidades registravam em seus compromissos a exclusão total das possibilidades de ter entre seus quadros irmãos libertos ou escravos, outras admitiam essa possibilidade e outras se organizavam exatamente em torno desses grupos. Essa tendência de criar irmandades segundo as hierarquias sociais que marcava a sociedade, é herdada de Portugal em cujas confrarias consideradas mais ricas reuniam homens brancos e impediam a entrada daqueles que não possuíam pureza de sangue e patrimônio. Assim, cativos e mesmo pretos e pardos libertos, excluídos dessas agremiações tiveram que criar suas próprias devoções.

A Santa Casa de Misericórdia da Bahia impunha para admitir alguém entre seus confrades a condição de ser portador de honestidade, capacidade de ganhar a própria vida e possuir sangue puro (MATTOSO, 2003, p. 222). Estes três pré-requisitos se não simultaneamente, pelo menos o último inviabilizava a adesão de negros nesta irmandade, pois para ter sangue puro se fazia necessário além de não ter origem judaica, não possuir pessoa de cor na família, nem como cônjuge, nem como descendente.

O Compromisso de Santa Casa de Misericórdia do Maranhão, do ano 1841, além de definir um total de 320 irmãos (Cap. I, Art.1 ${ }^{\text {o }}$ ) determina que deveria haver ainda um total de 15 irmãos supranumerários, dentre os quais 8 deveriam ser letrados. (Art. $2^{\circ}$ ). Determina também que para qualquer ser admitido irmão, deveria ter as seguintes qualidades:

Parágrafo $1^{\circ}$. Ser temente a Deus, modesto e caritativo;

Parágrafo $2^{\circ}$. Ser maior de 21 anos;

Parágrafo $3^{\circ}$. Ter bom entendimento e saber, não podendo, portanto, ser admitido o que não souber ler, escrever e contar;

Parágrafo $4^{\circ}$. Ser abastado em fazendas, de maneira que possa acudir ao serviço da irmandade sem cair em necessidade, e sem incorrer na suspeita de se aproveitar do que correr por suas mãos;

Parágrafo $5^{\circ}$. não servir à irmandade de maneira alguma por salário. 
Conforme o texto citado, a Santa Casa de Misericórdia utilizava os critérios econômicos e culturais como forma de definir o perfil dos membros dessa agremiação, o que caracterizava uma estratégia para manutenção dos grupos que historicamente estiveram à frente desta irmandade, homens brancos, com alto poder aquisitivo, que se destacavam como benfeitores. Por outro lado, havia irmandades que dificultavam a participação dos brancos, como ocorreu na Irmandade de Nossa Senhora do Rosário dos Homens Pretos da Freguesia de Santo Antônio, em Pernambuco. Esta entidade em seu compromisso declarava que poderia admitir por irmão mestiços e pretos tanto nacionais quanto africanos (de Angola, Cabo Verde, S. Tomé e Moçambique e Costa da Mina), sendo cativos, livres ou forros. Também declara que aceita homens e mulheres brancos e pardos, com a condição de que "nunca se intrometerão nem terão voto nas eleições e nas determinações da irmandade" (QUINTÃO, 2002, p. 95).

Sendo assim, as irmandades de pretos se constituíram como alternativa para a agremiação de pessoas que, pela cor ou condição, viam-se impossibilitados a fazer parte de irmandades como a de Santa Casa de Misericórdia.

Dentre as irmandades de pretos, a mais antiga é a Irmandade de Nossa Senhora do Rosário, criada em Pernambuco como a primeira na América Portuguesa no final do século XVI, por missionários jesuítas. Contudo, fora do Brasil essa prática remonta ao século XV, quando foi fundada em Lisboa (1496) como concretização da política de incentivo á organização de irmandades para a população africana conduzida pelo Papa Gregório XII. Inicialmente, a criação de irmandades de pretos surge com o objetivo de doutrinar os escravos na liturgia católica (ISHAQ, 2006, p.67-70). São santos de devoção das irmandades de pretos facilmente identificados no Brasil: Nossa Senhora do Rosário, São Benedito, Santa Efigênia, São Elesbão, Nossa Senhora da Conceição, Santo Antonio, São Gonçalo, São Domingos e Nossa Senhora da Lampadosa (FARIAS, 2006, p. 103).

Enquanto pode-se identificar uma variedade de irmandades com invocação diferenciada de Santo, não se pode afirmar que nestas confrarias encontravam-se apenas pessoas negras. Em geral, não havia o veto explícito a brancos, pois muitas vezes por carência de pessoas negras com domínio dos saberes da instrução, recorriam-se aos brancos para ocupar cargos que exigiam o uso destes conhecimentos. Havia também o interesse da 
irmandade de contar com membros brancos detentores de propriedade que pudessem contribuir com doações que os favorecessem.

A Irmandade da Virgem Nossa Senhora do Rosário da cidade de Caxias em compromisso aprovado em 4 de maio de 1856 define que:

Toda a pessoa católica de ambos os sexos, poderá ser irmão, uma vez que seja temente a Deus, modesta, caritativa, de bons costumes, e tendo uma profissão honesta, que ofereça garantias no cumprimento dos seus deveres. (Art. $1^{\circ}$ ). O candidato que tiver as qualidades do antigo antecedente, e quizer ser admitido como irmão, deverá o dizer a mesa por sua petição, ou a seu presidente, o sendo deferido, assignará com o mesmo presidente o respectivo termo lavrado pelo Secretário, e se for cativo por seus senhores em que se sujeitem a contribuir com as pensões da irmandade ficando insentos de todos os empregos, salvo os de juízes, Rei, Rainha e Mordomos (Art. $2^{\circ}$ ).

Nesta entidade fica evidente a aceitação de escravos como membros da irmandade, bem como aparece, entre os principais cargos da confraria, as funções de Rei e Rainha. Reis e rainhas nas confrarias de pretos correspondiam aos cargos que caracterizavam a formação de uma corte negra responsável pela realização da festa do santo de devoção da irmandade. Segundo Vainfas (2002, p. 629):

Os reis negros das irmandades davam uma contribuição monetária que deveria ser empregada na realização da festa, assim como arrecadavam doações que seriam nela aplicadas. Por ocasião da festa, no dia do orago da irmandade, desfilavam com a sua corte, vestidos com mantos, coroas e cetros. Eram coroados pelo padre na missa da festa, percorriam as ruas acompanhados de músicas e danças de origem africanas.

O ato de coroação da corte negra, apesar de ocorrer no contexto das influências cristãs católicas, tem raízes "no antigo reino do Congo, onde alguns chefes, após os primeiros contatos com os portugueses, adotaram formas africanas de cristianismo" (VAINFAS, 2002, p. 630).

A escolha de uma corte negra tendeu a desaparecer no decorrer do século XIX, dado ao cerceamento da comunidade negra. Em muitos casos, a própria Igreja Católica considerava as manifestações de origem africana no interior das irmandades como práticas que desvirtuavam a liturgia cristã. As conseqüências desse processo podem ser observadas no compromisso das entidades na Província do Maranhão.

Em compromisso da Irmandade da Virgem Nossa Senhora do Rosário da cidade de Caxias, aprovado em 1865, fica suprimido o ato de escolha e coroação da corte negra, 
bem como, fica vetada na entidade a entrada de membros escravos, o que contrasta com o documento de 1856 citado anteriormente:

Toda a pessoa, quer de um sexo quer de outro, sendo livre, católica, temente a Deus, modesta, caritativa, de bons costumes, e tendo uma profissão, honesta d' onde possa auferir lucros, que garantem as obrigações, que se impuser pelo presente compromisso, poderá ser admitida para irmão de Nossa Senhora do Rosário (Art. $1^{\circ}$, cap. $1^{\circ}$ ).

$\mathrm{O}$ candidato que tiver as qualidades especificadas no art. Antecedente, desejando ser admitida em o número de irmãos, deverá dirigir uma petição verbal, ou escrita, à mesa administrativa da irmandade, a qual, depois de tomar em consideração a mesma petição, e achando que o peticionário reúne os requisitos necessários, deferirá na forma requerida (Art. $2^{\circ}$, cap. $1^{\circ}$ ).

Após a reformulação do Compromisso desta irmandade, pode-se perceber com clareza o processo de transformação que vai ocorrer com as irmandades negras no decorrer do século XIX, quando o governo desestimula as distinções étnicas nos compromissos dessas confrarias. Essa questão pode ser confirmada em diversos compromissos aprovados no Maranhão durante o século XIX, dos quais aparecem em impressos de leis provinciais a partir da década de 40.

O Compromisso da Irmandade Nossa Senhora do Rosário da Capital, aprovado em 1851, define que podem ser irmãos pessoas de ambos os sexos, desde que honestas e "queiram por sua devoção concorrer com seus bens, e serviços para o maior esplendor do culto da Nossa Senhora do Rosário e se for pessoa escrava deverá apresentar licença por escrito do seu senhor" (Art. $2^{\circ}$ ).

Além da aceitação de escravos entre os irmãos, há no artigo 30 e no artigo 34 a referência à coroação da corte negra:

Todos os anos em dias de Reis se celebrará a festividade de Nossa Mãe Santísssima Senhora do Rosário com toda a grandeza possível, feita pelos quatro festeiros de cada ano - sendo Rei e Rainha, Juiz e Juíza: no fim da festa o Celebrante da Missa coroará os novos Reis e Rainhas, e tomarão posse os Juízes [...] (Art. 30)

Haverá igualmente Príncipes e Princesas nomeados dentre os Irmãos, e Irmães, os quais pagarão de jóia a quantia de dois mil réis.

Apesar da irmandade registrar em seu compromisso como membro todas as pessoas sem distinção econômica, de sexo ou condição (livre ou cativo), em nenhum momento do documento há referência à cor ou estado das pessoas que devem ocupar os cargos de rei e rainha, do que se pode conclui haver uma unanimidade de que estas posições deveriam ser ocupadas por pessoas negras. $\mathrm{O}$ mesmo não ocorre quando a 
intenção é caracterizar as funções de juiz e juíza, pois há indicação de que (artigo 26) essas funções poderiam ser ocupadas por qualquer pessoa, ainda mesmo que não fossem irmãos. Ainda no artigo 26, fica evidenciado que essa função cabe principalmente a irmãos brancos. A exemplo da Irmandade de Nossa Senhora do Rosário da Capital, que aceita negros escravos entre seus membros, podemos destacar outros dois exemplos de irmandades que existiram no Maranhão. A irmandade do Senhor Bom Jesus da Cana Verde, erguida no Convento de Nossa Senhora das Mercês, em São Luís, em Compromisso do ano de 1852, declara aceitar como confrade "qualquer cidadão, sendo estes livres ou cativos", mas indica que "nunca o número de irmãos livres deve ser superior ao dos cativos".

Dentre os compromisso consultados, esta irmandade revelou-se a que mais pode ser caracterizada como confraria de escravos. Em outros momentos do texto, fica confirmada a suspeita, quando define que os cargos de provedor, secretário, zelador e tesoureiro devem ser ocupados "serão pessoas livres" e "doze mesários, cuja maioria deve ser composta de cativos". Sobre a possibilidade de um irmão cativo vir a libertar-se, afirma que "não serão expelidos da irmandade, ainda que por este fato fique superior o número de irmãos livres".

Em contrapartida, havia irmandades que aceitavam escravos, mas restringiam a sua participação em cargos. A Irmandade da Gloriosa Santa Efigênia, ereta na Igreja de Nossa Senhora do Rosário, também em São Luís, no Art. 40 do compromisso aprovado em 1855, exclui da possibilidade de concorrer a cargos, além dos menores de 21 anos, os que estiverem devendo a entidade e os escravos.

Devido ao elevado nível de organização das irmandades, fica patente a ocorrência de práticas sociais inerentes ao contexto letrado. Necessitava-se de conhecimentos da escrita, pelo menos para assinar o nome na petição de ingresso na entidade, em um nível mais avançado escrevia-se a própria petição ou podia-se concorrer aos principais cargos da mesa administrativa (secretário, tesoureiro, provedor, zelador e procurador).

De qualquer forma, não parece regra uma total ausência das habilidades de leitura e escrita por parte dos confrades, como evidenciado nos compromissos em vários 
momentos. O Compromisso da Irmandade do Glorioso São João Batista, freguesia do Cururupu define que:

Art. $2^{\circ}$. Podem ser irmãos todas as pessoas de qualquer condição de um ou outro sexo, que sendo de costumes honestos e religiosos, queiram por sua devoção, concorrer com os seus bens e serviços para maior esplendor do culto do Glorioso São João Batista.

Art. $3^{\circ}$. Para ser admitido irmão é preciso que seja a pessoa por algum mesário, que o requeira por escrito, ou verbalmente à mesa e esta decida na conformidade do artigo antecedente.

Capítulo II

Das obrigações dos irmãos em geral

(...) Parágrafo 3. Assinar termo por si, ou por seu procurador, de sujeição às disposições deste compromisso.

Neste compromisso pode-se observar que há valorização tanto da prática da linguagem verbal quanto da linguagem escrita. A simultaneidade de citação dessas duas formas de linguagem indica a existência de confrades tanto na situação de alfabetizados como na situação de analfabetos. O mesmo fica evidenciado quando há referência às obrigações dos irmãos: "é obrigatório assinar o nome em termo de sujeição ao compromisso, contudo quem não o sabe pode instituir um procurador".

O Compromisso de Nossa Senhora do Rosário apresenta como condição para adesão dois pólos, conforme ocorre com a Irmandade de São João Batista (apresentada anteriormente), contudo exclui a figura do procurador na assinatura de termo de sujeição às leis do compromisso:

Art. $3^{\circ}$. Para ser admitido irmão é necessário que a pessoa o requeira à mesa ou escrito, ou verbalmente, e esta decida na conformidade do antigo antecedente.

Art. $4^{\circ}$ para se assentar por irmão é necessário que a pessoa admitida entre para os cofres com a oblação de mil reis pelo menos, e que assine termo de sujeição às leis deste compromisso e se obrigue à pagar em cada ano civil a prestação de trezentos e vinte reis.

Mas há ainda um terceiro caso, em que os compromissos suprimem a petição para adesão de forma verbal, do que se pode crer que a irmandade contava com significativo número de confrades letrados. A irmandade do Glorioso São Benedito da Freguesia de São Francisco Xavier do Turiaçu registra a questão da seguinte forma:

Art. $1^{\circ}$. [...] será composta de todas as pessoas de ambos os sexos, sem distinção, contanto que professem a religião Católica, que tenham mais de 12 anos de idade, e que por seu comportamento e bons costumes se possa esperar que cumpram o seu dever [...].

Art. 5. A pessoa que pretender inscrever-se irmão fará petição à mesa para o dito fím, declarando sua naturalidade, filiação, estado, idade e lugar de sua residência. 
Tal aspecto pode ser apreciado também em estatutos de outras entidades como é o caso da Sociedade Beneficente Fim Humanitário sob a proteção do Senhor Bom Jesus da Cana Verde. Nesta entidade para tornar-se sócio fazia-se necessário enviar:

requerimento assinado pelo interessado que nele deve declarar seu nome, idade, nacionalidade, estado, profissão, residência e nome do seu senhor quando do requerente seja escravo; devendo neste último caso vir o requerente acompanhado de licença passada pelo mesmo senhor para este fim; atestando este na mesma licença a conduta do seu escravo.

Do mesmo modo que no estatuto se dá importância para o ato de assinar, mesmo quando na condição de escravo, o requerimento de adesão. No Art. $9^{\circ}$ do mesmo documento, indica-se ser relevante o domínio da leitura, pois se declara que "aprovado seja o candidato, o primeiro secretário lhe comunicará por escrito, remetendo-se um exemplar dos estatutos". Essa entidade parece diretamente ligada à própria irmandade Bom Senhor da Cana Verde, ereta na Igreja das Mercês, pois no artigo $5^{\circ}$ do estatuto declara-se que o requerente a sócio da entidade que for membro da irmandade Senhor Bom Jesus da Cana Verde, deverá apresentar "recibo onde mostre achar-se quite com a irmandade".

Ainda preocupados em envolver seus sócios na prática da escrita e leitura, a Sociedade Fim Humanitário Senhor Bom Jesus da Cana Verde registra, no artigo 82 do seu estatuto, o compromisso de estimular a instrução dos sócios analfabetos.

Art. 82. Se a maioria dos sócios analfabetos anuir, criará a assembléia geral uma aula noturna de instrução primária, que funcionará duas vezes semanalmente e cujas despesas com casa, livros, luzes, ocorrerão por conta dos sócios que a freqüentarem devendo a assembléia Geral concorrer quando possível com a sua animação e desenvolvimento, dotando-a de um professor habilitado, o qual será escolhido dentre os membros da mesa diretora e servirá gratuitamente.

Se observarmos o Estatuto da Sociedade Beneficente - Fim Humanitário - sob

a proteção do Senhor Bom Jesus da Cana Verde, em seu Arts. 79 e 80, elaborado em 1879, podemos identificar também o desempenho de função manumissora, ao definir regras para contemplar sócios escravos com a libertação:

Art. 79. A sociedade todos os anos, três meses antes da solenização do aniversário de sua instalação, por meio de uma subscrição promovida entre todos os sócios e particulares, até a quantia de cento e cinqüenta mil reis, adicionada de cinqüienta mil reis que deverão ser tirados de seus cofres, é obrigada a concorrer para resgate de liberdade de um sócio escravo, sem distinção de sexo com a soma de duzentos mil reis.

Art. 80. Será concedido esse favor em virtude do prêmio maior que o sócio escravo obtenha na loteria que a sociedade para tal fim promulgará. 


\section{Considerações finais}

O presente estudo demonstra que durante o século XIX, quando os discursos e as preocupações das elites estiveram voltados para o desafio de tornar o Brasil uma nação civilizada, o negro foi considerado ser boçal, e por isso, visto como incapacitado para a integração no contexto civilizado.

Contudo, na Província do Maranhão, fica evidenciado pela documentação analisada, que mesmo negros na condição de escravos se apropriavam de símbolos de civilidade como forma de serem confundidos com pessoas livres. Na imprensa do período há maior evidência de referências sobre os negros nos anúncios de compra, venda e aluguel de escravos, além dos informes que descrevem negros fugidos. Tais anúncios revelam-se riquíssimos para a compreensão da vida dos negros durante o período em questão, e servem também para desmistificar os discursos dos letrados que muitas vezes, nestes mesmos jornais, caracterizavam os escravos de forma pejorativa.

Observou-se também, que, embora desfrutando de uma condição diferenciada no sistema escravista, embora à margem, os negros de alguma forma estiveram viabilizando meios de inserirem-se no contexto sócio-cultural vigente.

A adesão às irmandades se destaca como uma das formas encontradas por eles, visando uma vivência integrada na sociedade brasileira e maranhense. As Irmandades de Pretos não se diferenciavam substancialmente das demais confrarias da época. Possuíam em comum todo um aparato legal e uma estrutura organizativa, cujas práticas de leitura e escrita se consagravam como habilidades necessárias ao bom andamento da própria instituição. O fato de haverem instituições do nível organizativo das irmandades religiosas congregando negros, inclusive na condição de escravos, revela que esse segmento visava implementar estratégias para garantir a sua inserção o mais plenamente possível no conjunto de práticas culturais consideradas legítimas pela sociedade vigente. O que nos leva a concluir que as vivências culturais do período não podem ser concebidas como práticas culturais eminentemente restritas a um ou outro grupo.

Sendo assim, podemos afirmar que a secularização da miséria entre os grupos de descendentes de africanos, no Brasil e no Maranhão, não pode ser justificada como resultado das limitações naturais das camadas desse grupo de se incorporar no universo 
cultural legitimado como condição para a inclusão sócio-econômica, como a literatura histórica mais tradicional afirma, mas sim, como conseqüência da existência de barreiras sociais impostas conforme a cor da pele, desde os tempos mais remotos da história brasileira.

\section{REFERÊNCIAS}

\section{BIBLIOGRAFIA:}

APEM. Documento para a história da Balaiada. São Luís: Edições FUNCMA, 2001.

ARAUJO, Mundinha. Insurreição de escravos em Viana - 1867. 2. ed. São Luís: Edições AVL, 2006.

COE, Agostinho Júnior Holanda. "A morte no século XIX e a transferência dos enterros das igrejas para os cemitérios em São Luís." Outros Tempos: pesquisa em foco. Disponível em: www.outrostempos.uema.br/anaisagostinho.htm

COSTA, Emília Viotti da. Da senzala à colônia. 4. ed. São Paulo: Unesp, 1998.

FARIAS, Juliana Barreto; GOMES, Flávio dos Santos; SOARES, Carlos Eugênio Líbano et al. Cidades Negras: africanos, crioulos e espaços urbanos no Brasil escravista do século XIX. São Paulo: Alameda, 2006.

ISHAQ, Vivien. Irmãos na terra e no céu. Revista Nossa História. Rio de Janeiro: Editora Vera Cruz, ano 3, n. 35 setembro de 2006.

MATTOSO, Kátia de Queirós. Ser escravo no Brasil. 3. ed. São Paulo: Brasiliense, 2003.

MENDONÇA, Joseli Nunes. Cenas da abolição: escravos e senhores no parlamento e na justiça. São Paulo: Fundação Perseu Abramo, 2001.

MORAES, Jomar. Guia de São Luís do Maranhão. São Luís: Lithograf, 1995.

MOTA, Antônia da Silva; SILVA, Kelcilene. R.; MANTOVANI, José. São Luís do Maranhão no século XVIII: a construção do espaço urbano sob as leis das sesmarias. São Luís: FUNC/ MA, 1998.

MOTA, Antônia da Silva. "Testamentos e inventário do preto forro Vitoriano Ramos da Silva”: Maranhão, 1802. Ciências Humanas em Revista. São Luís, 2005, v. 3, n. 01.

QUINTÃO, Antônia Aparecida. Lá vem o meu parente: as irmandades de pretos e pardos no Rio de Janeiro e Pernambuco, séc XVIII. São Paulo: Fapesp/Annablume, 2002. 
SCHWARTZ, Stuart B. Segredos internos: engenhos e escravos na sociedade colonial, 1550-1835. São Paulo: Companhia das Letras, 2005.

SOARES, Carlos Eugênio Líbano. A Capoeira escrava e outras tradições rebeldes no Rio de Janeiro: 1808- 1850. 2. ed., Campinas: Unicamp/Centro de Pesquisa em História Social da Cultura, 2002.

VAINFAS, Ronaldo (org.). Dicionário do Brasil Imperial: 1822-1889. Rio de Janeiro: Objetiva, 2002.

\section{IMPRENSA}

Diário do Maranhão, Publicador Maranhense, O Paiz, Civilização.

\section{COMPROMISSO DE IRMANDADES (IMPRESSOS)}

MARANHÃO. Compromisso da Santa Casa de Misericórdia de 20 de setembro de 1841. Coleção dos Regulamentos Expedidos pelo governo provincial para execução das leis da Assembléia da Província do Maranhão nos anos de 1835 a 1848. Maranhão, Tipografia Constitucional de I. J. Ferreira, 1849.

Lei 324. de 2 de outubro de 1852. Aprova o Compromisso da Irmandade Bom Jesus da Cana Verde. Coleção dos Regulamentos Expedidos pelo governo provincial para execução das leis da Assembléia da Província do Maranhão nos anos de 1849-1854 Maranhão, Tipografia Constitucional de I. J. Ferreira. 1854

Lei 302, de 10 de novembro de 1851. Aprova o Compromisso da Irmandade de Nossa Senhora do Rosário, na Capital. Coleção das leis, decretos e resoluções da Província do Maranhão, São Luís: Tipografia Constitucional, v. 1849-1856, 1852.

. Lei 479, de 18 de Julho de 1858. Aprova o Compromisso da Irmandade de São Benedito, de Viana. Coleção das leis, decretos e resoluções da Província do Maranhão, São Luís: Tipografia Constitucional, v. 1858-1864, 1859.

Lei de 4 de maio de 1856. Compromisso da Irmandade da Virgem Nossa Senhora do Rosário da cidade de Caxias.Coleção de Leis, Decretos e Resoluções da Província do Maranhão Tipografia Constitucional de I. J. Ferreira, v. 1854-7, São Luís, 1957.

. Lei 736, de 7 de julho de 1865. Compromisso da Irmandade da Virgem Nossa

Senhora do Rosário da cidade de Caxias.Coleção de Leis, Decretos e Resoluções da Província do Maranhão Tipografia José Mathias, v. 1865-6, 1966. 
Lei 786, de 11 de julho de 1866. Compromisso da Irmandade de São Benedicto, da Freguesia de São Francisco Xavier do Turiaçu. Maranhão, Coleção de Leis, Decretos e Resoluções da Província do Maranhão, São Luís, Tipografia José Mathias, v. 1865-6, 1966.

Lei de 16 de julho de 1866. Compromisso da Irmandade de São do Glorioso São João Batista, Padroeiro da Freguesia do Cururupu, Coleção de Leis, Decretos e Resoluções da Província do Maranhão, São Luís, Tipografia José Mathias, v. 1865-6, 1966.

- Lei 1.056, de 16 de julho de 1874. Aprova alterações no Compromisso da Irmandade do Senhor Bom Jesus da Cana Verde. Coleção de leis, decretos e resoluções da Província do Maranhão, São Luís: Tipografia Paiz, v. 1874,

Portaria de 2 de novembro de 1879. Aprova o Estatuto da Sociedade Beneficente Fim Humanitário. Coleção de leis, decretos e resoluções da Província do Maranhão, São Luís, Tipografia Paiz, v. 1877-80, 1880. 